\title{
G Antigen 2A
}

National Cancer Institute

\section{Source}

National Cancer Institute. G Antigen 2A. NCI Thesaurus. Code C104378.

G antigen 2A (116 aa, $\sim 13 \mathrm{kDa}$ ) is encoded by the human GAGE2A gene. This protein may be involved in tumorigenesis. 